\title{
Tau, amyloid, and hypometabolism in the logopenic variant of primary progressive aphasia
}

Figure $\quad{ }^{18} \mathrm{~F}-\mathrm{FDG},{ }^{18} \mathrm{~F}-\mathrm{fl}$ orbetapir, and ${ }^{18} \mathrm{~F}-\mathrm{AV}-1451$ PET superimposed to native MRI
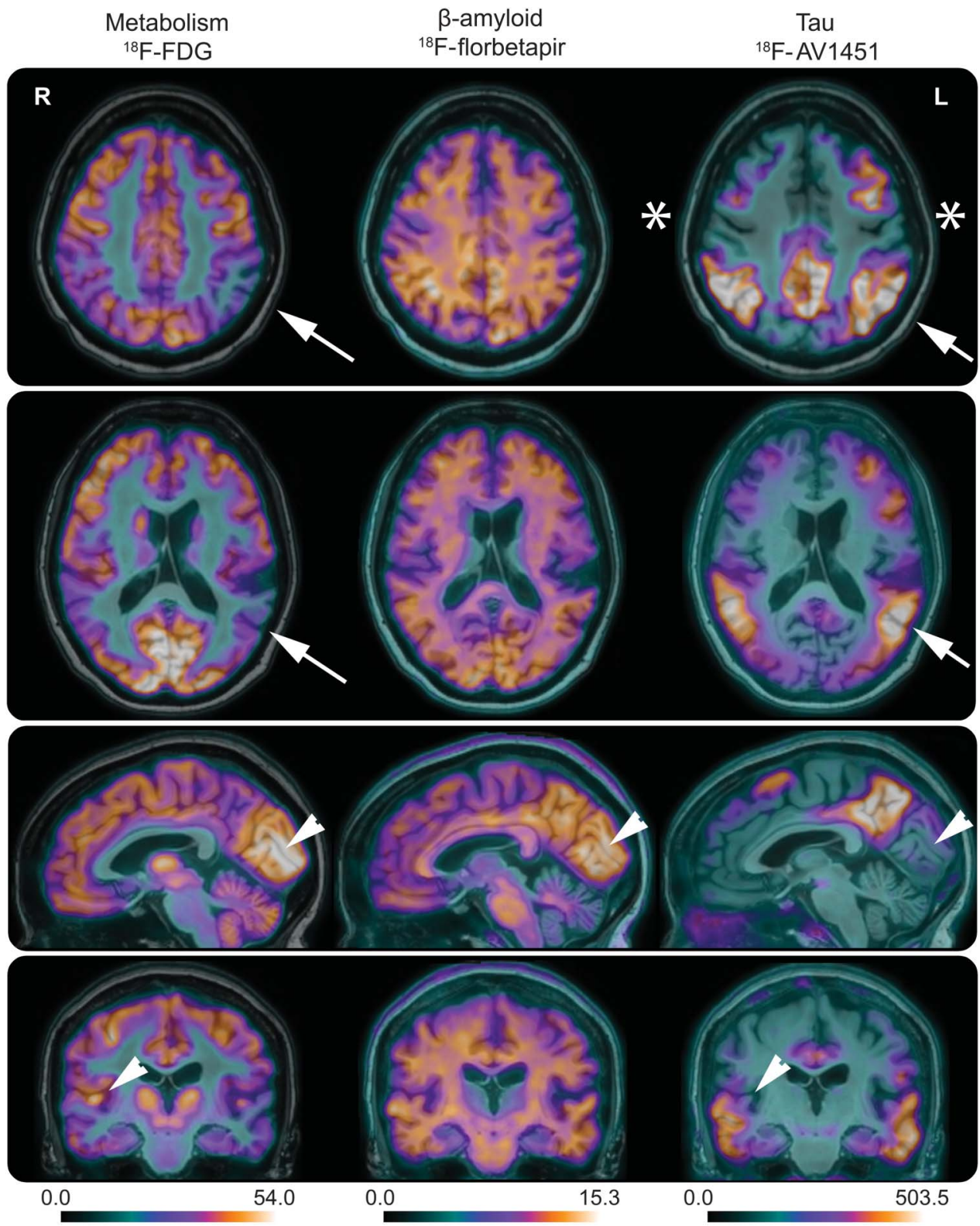

Primary sensory-motor areas (asterisks), as well as the primary visual (striatal cortex) and auditory (Heschl gyrus) regions (arrowheads), have normal metabolism and no tau deposition. Areas with high tau deposition (e.g., inferior parietal lobule, arrows) have decreased metabolism. Avid Radiopharmaceuticals provided the precursor for ${ }^{18} \mathrm{~F}-\mathrm{AV}-1451$.

A 57-year-old right-handed woman had an 8-year history of progressive word retrieval and repetition deficits, consistent with the logopenic variant of Alzheimer disease. ${ }^{1}$ She was studied using the novel hyperphosphorylated-tau tracer ${ }^{18} \mathrm{~F}-\mathrm{AV}-1451,{ }^{2}$ in conjunction with metabolic $\left({ }^{18} \mathrm{~F}\right.$-fluorodeoxyglucose [FDG] $)$ and $\beta$-amyloid $\left({ }^{18} \mathrm{~F}-\right.$ florbetapir) PET (figure). Areas with high tau, such as the left inferior parietal lobule, had decreased 
metabolism. By contrast, some areas with high amyloid, such as striated cortex, had normal metabolism. This case illustrates tau sparing of primary cortex and provides preliminary in vivo evidence that regional tau is more closely linked to hypometabolism than amyloid density.

Belen Pascual, PhD, Joseph C. Masdeu, MD, PhD

From the Nantz National Alzheimer Center, Houston Methodist Neurological Institute, TX; and Weill Cornell Medical College, New York, NY.

Study funding: Harrison Fund, Houston Methodist Hospital Foundation.

Disclosure: B. Pascual reports no disclosures relevant to the manuscript. J. Masdeu is a consultant for General Electric Healthcare and has received research support from Avid Radiopharmaceuticals. Go to Neurology.org for full disclosures.

Correspondence to Dr. Pascual: bpascual@houstonmethodist.org

1. Gorno-Tempini ML, Hillis AE, Weintraub S, et al. Classification of primary progressive aphasia and its variants. Neurology 2011;76:1006-1014.

2. Ossenkoppele R, Schonhaut DR, Baker SL, et al. Tau, amyloid, and hypometabolism in a patient with posterior cortical atrophy. Ann Neurol 2015;77:338-342.

\section{AAN Guideline Recommends Removal of Player if Concussion Suspected}

Athletes who are suspected of having a concussion should be removed from the game immediately and not be returned until assessed by a licensed health care professional trained in diagnosing and managing concussion. That is one of the recommendations of the American Academy of Neurology's highly accessed evidence-based guideline for evaluating and managing athletes with concussion.

Share this information with patients, families, coaches, athletic trainers, and colleagues. Visit $A A N . c o m / c o n c u s s i o n$ for all your concussion resources:

- Read the published guideline

- Access PDF summaries for clinicians, coaches, athletic trainers, and patients

- Download the slide presentation

- Review a clinical example

- Download the Academy's convenient mobile app, Concussion Quick Check, to quickly help coaches and athletic trainers recognize the signs of concussion.

For more information, contact Julie Cox at jcox@aan.com or (612) 928-6069. 


\section{Neurology}

Tau, amyloid, and hypometabolism in the logopenic variant of primary progressive aphasia

Belen Pascual and Joseph C. Masdeu

Neurology 2016;86;487-488

DOI 10.1212/WNL.0000000000002340

\section{This information is current as of February 1, 2016}

Updated Information \& Services

References

Subspecialty Collections

Permissions \& Licensing

Reprints including high resolution figures, can be found at: http://n.neurology.org/content/86/5/487.full

This article cites 2 articles, 1 of which you can access for free at: http://n.neurology.org/content/86/5/487.full\#ref-list-1

This article, along with others on similar topics, appears in the following collection(s):

Alzheimer's disease

http://n.neurology.org/cgi/collection/alzheimers_disease

Information about reproducing this article in parts (figures,tables) or in its entirety can be found online at:

http://www.neurology.org/about/about_the_journal\#permissions

Information about ordering reprints can be found online:

http://n.neurology.org/subscribers/advertise

Neurology ${ }^{\circledR}$ is the official journal of the American Academy of Neurology. Published continuously since 1951, it is now a weekly with 48 issues per year. Copyright @ 2016 American Academy of Neurology. All rights reserved. Print ISSN: 0028-3878. Online ISSN: 1526-632X.

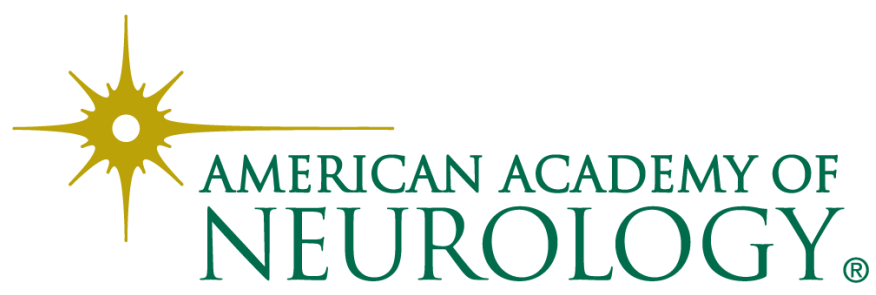

